\title{
CRYSTAL STRUCTURE AND ANTITUMOR ACTIVITIES OF THE DICHLORIDE 2,6-BIS(1-PHENYLBENZIMIDAZOL-2-YL)PYRIDINE COPPER(II) COMPLEX
}

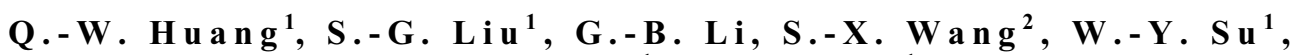 \\ D. - M. Li a n $\mathbf{g}^{1}, \mathrm{~S}$. - Q. M a o ${ }^{1}$ \\ ${ }^{1}$ School of Chemistry \& Chemical Engineering, Lingnan Normal University, Zhanjiang, P.R. China \\ E-mail:1sgui@sohu.com \\ ${ }^{2}$ Institute of Molecular Medicine, Medical School of Shenzhen University, Shenzhen, P.R. China
}

Received November, 24, 2013

Revised January, 06, 2015

\begin{abstract}
A new complex $\mathrm{Cu}(\mathrm{bpbp}) \mathrm{Cl}_{2} \cdot \mathrm{DMF} \cdot \mathrm{H}_{2} \mathrm{O}$ is synthesized by treatment of $\mathrm{CuCl}_{2}$ with 2,6-bis(1phenylbenzimidazol-2-yl)pyidine in DMF. Its structure is characterized by elemental, IR, UV, and single crystal X-ray structure analyses. For the complex: crystal system, triclinic, space group $P \overline{1}, \quad a=1.0537(1) \mathrm{nm}, \quad b=1.1735(1) \mathrm{nm}, \quad c=1.3749(2) \mathrm{nm}, \quad \alpha=112.275(2)^{\circ}$, $\beta=91.531(2)^{\circ}, \gamma=97.700(2)^{\circ}, V=1.553(4) \mathrm{nm}^{3}, Z=2$. In a distorted trigonal bipyramidal geometry the $\mathrm{Cu}(\mathrm{II})$ ion is coordinated by three nitrogen atoms from 2,6-bis(1-phenylbenzimidazol-2-yl)pyridine and two chloride ions. The antiproliferative activities of the complex are screened by MTT assay against HepG2, Huh7, Eca109, and Eca9706 cancer cells. The complex exhibits specific inhibition on Eca9706 cancer cells with the $\mathrm{IC}_{50}$ value of $28 \mu \mathrm{M}$ after 48 h treatment. CCDC: 968927.
\end{abstract}

DOI: $10.15372 / \mathrm{JSC} 20150308$

K e y w o r d s : benzimidazole, copper complex, crystal structure, antitumor activities.

The widespread success of cisplatin in the clinical treatment of various types of neoplasias has placed coordination chemistry of metal-based drugs in the frontline in the fight against cancer [ $1-4]$. The cure with cisplatin is still limited by dose-limiting side effects and inherited or acquired resistance phenomena. These problems have stimulated an extensive search and prompted chemists to develop alternative strategies based on different metals with improved pharmacological properties and aimed at different targets. However, the accumulation of metal ions in the body can lead to deleterious effects and unavoidable toxicity. Thus, biodistribution and clearance of the metal complex as well as its pharmacological specificity need to be considered [5]. Benzimidazole derivatives are important pharmacophores in drugs that display a diversity of pharmacological activities, such as anti-inflammatory, antioxidant, gastroprotective, and antiparasitic activities [6]. Many DNA minor groove binders containing one or more benzimidazole heterocycles endowed with promising antitumor and antiparasitic activities have been reported to date [ 7,8$]$. Studies have showed that the intercalating abilities of the complexes depended on the types of metal ions, the ligand donor atoms, the planarity of ligands, and the coordination geometry [9]. In our previous study, two zinc complexes based on 2,6-bis(1phenylbenzimidazol-2-yl)pyridine have been synthesized and evaluated for in vitro anticancer activities $[10]$.

Copper is an essential element for most aerobic organisms employed as a structural and catalytic cofactor, and consequently, it is involved in many biological pathways [11-13]. Several strategies aimed at the development of new anticancer therapeutics targeting the elevated tumor-specific copper

(C) Huang Q.-W., Liu S.-G., Li G.-B., Wang S.-X., Su W.-Y., Liang D.-M., Mao S.-Q., 2015 
level have been proposed [ 14,15$]$. In this article, we synthesized a new copper(II) complex based on 2,6-bis(1-phenylbenzimidazol-2-yl)pyridine and investigated its antitumor activities. The result demonstrates that the dichloride 2,6-bis(1-phenylbenzimidazol-2-yl)pyridine copper(II) complex has high proliferation inhibition toward Eca9706 cancer cells in vitro.

Experimental. General. $o$-Phenylenediamine, pyridine-2,6-dicaboxyl acid, bromobenzene, and $\mathrm{CuCl}_{2}$ were purchased from Shanghai Aladdin Reagent Company. All the chemicals and solvents were analytically pure and used without further purification. The analyses $(\mathrm{C}, \mathrm{H}$, and $\mathrm{N})$ were made on a Perkin-Elmer 240C elemental analyzer. The solid infrared spectra (IR) were obtained from a Bruker IFS66V vacuum-type FT-IR spectrophotometer in $\mathrm{KBr}$ pellets. The UV absorption spectra were recorded on a model UV-240 spectrophotometer (Shimadzu, Japan). The synthesis of 2,6-bis(1-phenylbenzimidazol-2-yl)pyridine (bpbp) was accorded to the literature method [16].

Synthesis of the $\mathbf{C u}(\mathbf{b p b p}) \mathbf{C l}_{2} \cdot \mathbf{D M F} \cdot \mathbf{2} \mathbf{H}_{2} \mathrm{O}$ complex. A solution of $\mathrm{CuCl}_{2}(0.135 \mathrm{~g}, 1.0 \mathrm{mmol})$ in $5 \mathrm{ml}$ of water was added to a hot stirred solution of bpbp $(0.464 \mathrm{~g}, 1.0 \mathrm{mmol})$ in $30 \mathrm{ml}$ of DMF. The reaction mixture was stirred for $20 \mathrm{~min}$ at room temperature. After two weeks, blue crystals were obtained from the DMF solution. Yield $0.239 \mathrm{~g}(80 \%)$. Calculated for $\mathrm{C}_{34} \mathrm{H}_{30} \mathrm{Cl}_{2} \mathrm{CuN}_{6} \mathrm{O}_{2}$ [Cu(bpbp)Cl $\left.\mathrm{Cl}_{2} \cdot \mathrm{DMF} \cdot 2 \mathrm{H}_{2} \mathrm{O}\right] \mathrm{C}, 59.26, \mathrm{H}, 4.39 \% \mathrm{~N}, 12.20 \%$ : found: $\mathrm{C}, 59.39 \%, 4.26, \mathrm{~N}, 12.10 \%$. Selected IR data $\left(\mathrm{KBr}, \mathrm{cm}^{-1}\right): 3415,3342,3069,2924,1668,1590,1501,1456,1384,1334,1300$, $1149,1093,994,887,814,753,680,647,613$.

X-ray crystallography. The single crystal structure determination of the complex was performed on a Bruker SMART APEX CCD diffractometer equipped with a normal focus, $3 \mathrm{~kW}$ sealed tube $\mathrm{X}$-ray source and graphite monochromated $\operatorname{Mo} K_{\alpha}$ radiation $(\lambda=0.71073 \AA)$ at $173 \mathrm{~K}$, operating at $50 \mathrm{kV}$ and $30 \mathrm{~mA}$. The structures were solved by direct methods using the SHELXTL program. Absorption correction was semi-empirical from the equivalents using the Fourier difference techniques and refined by full-matrix least-squares. All non-hydrogen atoms in both structures were refined by means of anisotropic displacement parameters. All hydrogen atoms were added theoretically. CIF file containing complete information on the studied structure was deposited with CCDC, deposition num-

$\mathrm{T} \mathrm{a} \mathrm{b} 1 \mathrm{e} 1$

Crystal data and structure refinement for the complex

\begin{tabular}{|c|c|}
\hline Empirical formula & $\mathrm{C}_{34} \mathrm{H}_{30} \mathrm{CuN}_{6} \mathrm{O}_{2}$ \\
\hline Formula weight & 689.07 \\
\hline Crystal system & Triclinic \\
\hline Space group & $P \overline{1}$ \\
\hline$a, b, c, \mathrm{~nm}$ & $1.0537(1), 1.1735(1), 1.3749(2)$ \\
\hline$\alpha, \beta, \gamma$, deg. & $112.275(2), 91.531(2), 97.700(2)$ \\
\hline$V, \mathrm{~nm}^{3}$ & $1.553(4)$ \\
\hline$Z$ & 2 \\
\hline$d_{\mathrm{c}}, \mathrm{g} / \mathrm{cm}^{-3}$ & 1.471 \\
\hline Absorption coefficient, $\mathrm{mm}^{-1}$ & 0.918 \\
\hline$F(000)$ & 708 \\
\hline Theta range for data collection & 1.61 to 25.01 \\
\hline Index ranges & $-12 \leq h \leq 12,-13 \leq k \leq 10,-16 \leq l \leq 14$ \\
\hline Independent reflections & $6878\left[R_{\mathrm{int}}=0.0202\right]$ \\
\hline Reflections collected & 5482 \\
\hline Data / restraints / parameters & $5294 / 0 / 418$ \\
\hline Goodness-of-fit on $F^{2}$ & 1.069 \\
\hline Final $R$ indices $[I>2 \sigma(I)]$ & $R_{1}=0.0451, w R_{2}=0.1330$ \\
\hline$R$ indices (all data) & $R_{1}=0.0671, w R_{2}=0.1625$ \\
\hline Largest diff. peak and hole, e/nm ${ }^{-3}$ & $0.662,-0.830$ \\
\hline
\end{tabular}


Fig. 1. UV-vis absorption spectra of the free ligand and the complex

ber 968927 , and is freely available upon request from the following website: www.ccdc.cam.ac.uk/data request/cif. The crystal data are summarized in Table 1.

Cell culture. The cell lines were obtained from American Type Culture Collection (ATCC, Manassas, VA) and maintained in the DMEM medium supplemented with fetal bovine serum $(10 \%)$, penicillin $\left(100\right.$ units $\left.\cdot \mathrm{ml}^{-1}\right)$, and streptomycin $\left(50\right.$ units $\left.\cdot \mathrm{ml}^{-1}\right)$ at $37{ }^{\circ} \mathrm{C}$ in a humidified incubator with $5 \% \mathrm{CO}_{2}$ in the

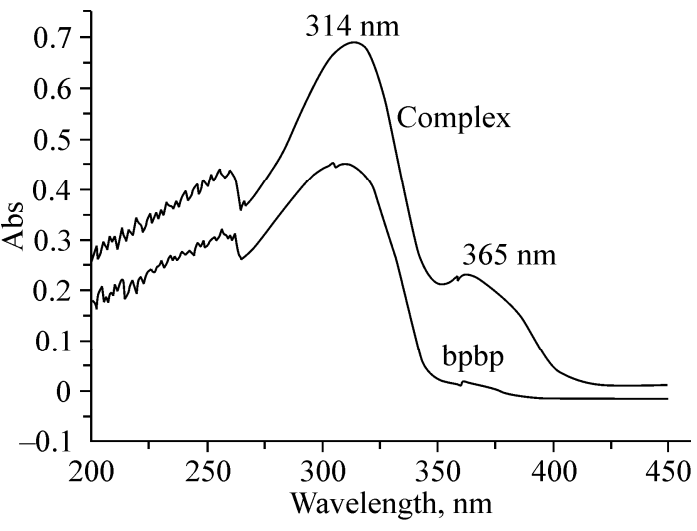
atmosphere.

MTT assay. The effects of the complex on cell proliferation were determined by the MTT assay. Briefly, the cells were seeded in 96-well culture plates at different densities. After $24 \mathrm{~h}$, different concentrations of compounds were added and incubated for the indicated time. Then, $20 \mu \mathrm{l}$ per well of the MTT solution ( $5 \mathrm{mg} \cdot \mathrm{ml}^{-1}$ phosphate buffered saline) was added and incubated for $5 \mathrm{~h}$. The medium was aspirated and replaced with $200 \mu \mathrm{l}$ per well of DMSO to dissolve the formazan salt formed. The color intensity of the formazan solution, which reflects the cell growth condition, was measured at $570 \mathrm{~nm}$ using a microplate spectrophotometer (VERSA max).

Results and discussion. IR, UV for the complex. The purity of the complex was carefully checked by the elemental analysis. Single crystals suitable for the X-ray crystallographic analysis were obtained by recrystallization from DMF. The IR spectra of the free bpbp ligand and the complex show all absorption bands resulting from the skeletal vibration of benzimidazole. In the complex there is a strong peak at $1668 \mathrm{~cm}^{-1}$, which shows DMF in this complex. The UV-vis absorption was recorded at a concentration of $1.0 \times 10^{-5} \mathrm{~mol} / \mathrm{l}$ in DMF at room temperature. The UV-vis absorption spectra of the free ligand and the complex are shown in Fig. 1. The ligand has absorption in the range of 270 $350 \mathrm{~nm}$ and the complex has absorption in the range of $270-400 \mathrm{~nm}$. The maximum ligand absorption is located at about $314 \mathrm{~nm}$, which can be assigned to intraligand $\pi \rightarrow \pi^{*}$ transitions. There is one more peak observed at $365 \mathrm{~nm}$ for the complex which probably arises from the metal-ligand charge transfer.

Crystal structure. The ORTEP drawing for the complex with atom numbering is shown in Fig. 2. The central $\mathrm{Cu}_{1}$ (II) atom has an $\mathrm{N}_{3} \mathrm{Cl}_{2}$ distorted trigonal bipyramidal geometry. The benzimida-

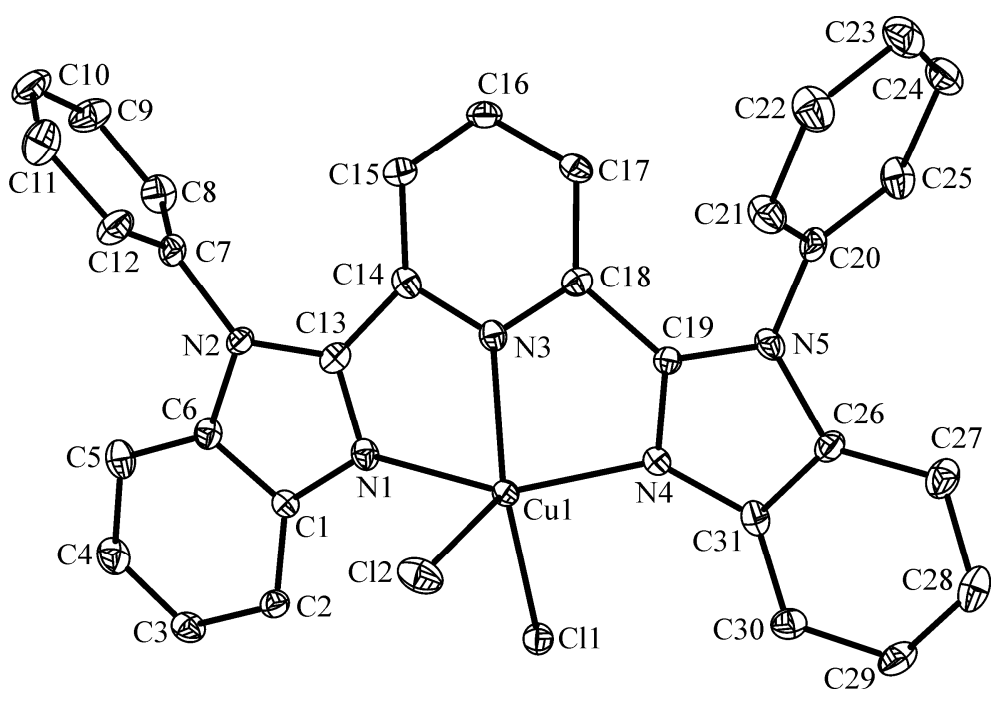

Fig. 2. Molecular structure of $\mathrm{Cu}(\mathrm{bpbp}) \mathrm{Cl}_{2}$ at a $30 \%$ probability. $\mathrm{H}$ atoms and solvents were omitted for clarity 


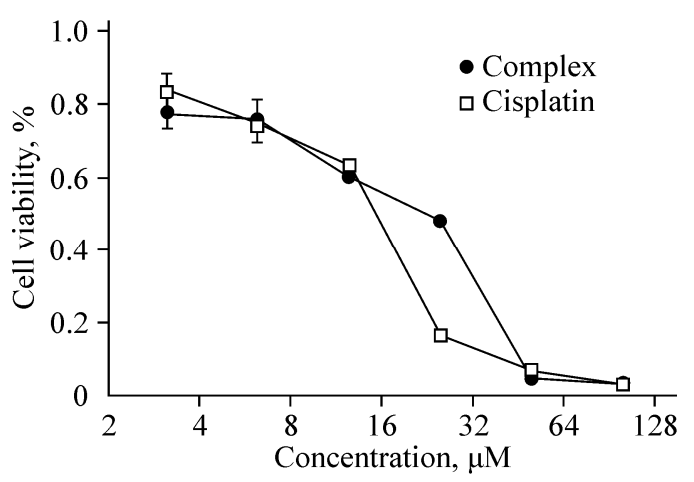

Fig. 3. Inhibition of the complex and cisplatin on Eca9706 cancer cells

T a b l e 2

Selected bong lengths (nm) and bond angles (deg.)

\begin{tabular}{l|l||l|r||l|r}
\hline $\mathrm{Cu} 1-\mathrm{N} 3$ & $0.1999(3)$ & $\mathrm{N} 3-\mathrm{Cu} 1-\mathrm{N} 4$ & $78.44(13)$ & $\mathrm{N} 3-\mathrm{Cu} 1-\mathrm{N} 1$ & $78.16(13)$ \\
$\mathrm{Cu} 1-\mathrm{N}(1)$ & $0.2038(3)$ & $\mathrm{N} 4-\mathrm{Cu} 1-\mathrm{N} 1$ & $155.05(14)$ & $\mathrm{N} 3-\mathrm{Cu} 1-\mathrm{C} 11$ & $160.82(10)$ \\
$\mathrm{Cu} 1-\mathrm{Cl} 2$ & $2.4837(12)$ & $\mathrm{N} 4-\mathrm{Cu} 1-\mathrm{Cl} 1$ & $100.22(10)$ & $\mathrm{N} 1-\mathrm{Cu} 1-\mathrm{Cl} 1$ & $99.03(10)$ \\
$\mathrm{Cu} 1-\mathrm{N} 4$ & $0.2034(3)$ & $\mathrm{N} 3-\mathrm{Cu} 1-\mathrm{Cl} 2$ & $99.17(10)$ & $\mathrm{N} 4-\mathrm{Cu} 1-\mathrm{Cl} 2$ & $97.45(10)$ \\
$\mathrm{Cu} 1-\mathrm{C} 11$ & $0.2244(1)$ & $\mathrm{N} 1-\mathrm{Cu} 1-\mathrm{Cl} 2$ & $94.69(10)$ & $\mathrm{C} 11-\mathrm{Cu} 1-\mathrm{Cl} 2$ & $99.97(4)$
\end{tabular}

zole rings and the central pyridine ring of the ligand together with $\mathrm{Cu}_{1}^{2+}$ form a plane (r.m.s. = $=0.0645^{\circ}$ ). The two $\mathrm{Cl}^{-}$ions are located on two sides of the plane formed by $\mathrm{N}_{1}, \mathrm{~N}_{3}, \mathrm{~N}_{4}$, and $\mathrm{Cu}_{1}$. The two substituted phenyl rings $\left(\mathrm{C}_{7}-\mathrm{C}_{12}, \mathrm{C}_{20}-\mathrm{C}_{25}\right)$ are inclined with their attached planar benzimidazole rings with the dihedral angles of $88.5^{\circ}$ and $87.1^{\circ}$ respectively. Selected bond lengths and angles for the complex are listed in Table 2. The average $\mathrm{Cu}-\mathrm{N}$ bond length is $2.021 \AA$, which falls into the range of normal $\mathrm{Cu}-\mathrm{N}$ distances.

The antiproliferative activities of the complex were screened by MTT assay against HepG2, Huh7, Eca109, and Eca9706 cancer cells. As shown in Fig. 3, the copper complex exhibits specific inhibition on Eca9706 cancer cells with $\mathrm{IC}_{50}$ of $28 \mu \mathrm{M}$ after $48 \mathrm{~h}$ treatment, with cisplatin $(12 \mu \mathrm{M})$ used as a positive control. The complex has no antitumor activities on HepG2, Huh7, and Eca109 cancer cells. The copper complex is a promising novel complex with the application potential in treatment of Eca9706 cancer.

Conclusions. A new complex $\mathrm{Cu}(\mathrm{bpbp}) \mathrm{Cl}_{2} \cdot \mathrm{DMF} \cdot \mathrm{H}_{2} \mathrm{O}$ was synthesized by treatment of $\mathrm{CuCl}_{2}$ with 2,6-bis(1-phenylbenzimidazol-2-yl)pyridine (bpbp) in DMF at room temperature. The complex was characterized by single X-ray crystal structure analyses. In the complex, the distorted trigonal bipyramidal geometry of the $\mathrm{Cu}$ (II) ion is coordinated by three nitrogen atoms from 2,6-bis(1-phenylbenzimidazol-2-yl)pyridine and two chloride ions. The antiproliferative activities of the complex were screened by MTT assay against HepG2, Huh7, Eca109, and Eca9706 cancer cells. The copper complex exhibits specific inhibition on Eca9706 cancer cells.

The authors thank the National Natural Science Foundation of China (No. 81201727 and No. 21403191) and the Natural Science Foundation of Guangdong Province (No. 2014A030307010) for providing financial support to this project.

\section{REFERENCES}

1. Hambley T.W. // Dalton Trans. - 2007. - 36. - P. 4929. - 4937.

2. Arnesano F., Natile G. // Coord. Chem. Rev. - 2009. - 253. - P. 2070. - 2081.

3. Ni W.X., Man W.L., Yiu S.M. et al. // Chem. Sci. - 2012. - 3. - P. $1582-1588$.

4. Mackay F.S., Woods J.A., Moseley H. et al. // Chem. Eur. J. - 2006. - 12. - P. 3155 - 3161.

5. Zhang C.X., Lippard S.J. // Curr. Opin. Chem. Biol. - 2003. - 7. - P. $481-489$.

6. Boiani M., Gonzalez M. // Mini-Rev. Med. Chem. - 2005. - 5. - P. 409 - 424. 
7. Joubert A., Sun X.W., Johansson E. et al. // Biochemistry. - 2003. - 42. - P. 5984 - 5992.

8. Mann J., Baron A., Opoku-Boahen Y. et al. // J. Med. Chem. - 2001. - 44. - P. 138 - 144.

9. Pyle A.M., Barton J.K. // Prog. Inorg. Chem. - 1990. - 38. - P. 413 - 475

10. Liu S.G., Cao W.Q., Yu L.L. et al. // Dalton Trans. - 2013. - 42. - P. 5932 - 5940.

11. Kraatz H.-B., Metzler-Nolte N. Concepts and models in bioinorganic chemistry. - Weinheim: Wiley-VCH, Germany, 2006.

12. Lippard S.J., Berg J.M. / Principles of bioinorganic chemistry. - Mill Valley: University Science Books, CA, 1994.

13. Frausto da Silva J.J.R., Williams R.J.P. The biological chemistry of the elements. - Oxford: Clarendon, UK, 1991.

14. Santini C., Pellei M., Gandin V. et al. // Chem. Rev. - 2014. - 114, N 1. - P. 815 - 862.

15. Bobrowska-Korczak B., Skrajnowska D., Tokarz A. // J. Biomed. Sci. - 2012. - 19. - P. 43. - 48.

16. Liu S.G., Chen Z.L., Su W.Y. et al. // Chin. J. Inorg. Chem. (Wuji Huaxue Xuebao). - 2013. - 29, N 2. - P. $403-408$ 